\title{
Unexpected diversity of Endozoicomonas in deep-sea corals
}

\author{
Christina A. Kellogg ${ }^{1, *}$, Zoe A. Pratte ${ }^{2}$ \\ ${ }^{1}$ US Geological Survey, St. Petersburg, Florida 33701, USA \\ ${ }^{2}$ Montana State University, Bozeman, Montana 59781, USA
}

ABSTRACT: The deep ocean hosts a large diversity of azooxanthellate cold-water corals whose associated microbiomes remain to be described. While the bacterial genus Endozoicomonas has been widely identified as a dominant associate of tropical and temperate corals, it has rarely been detected in deepsea corals. Determining microbial baselines for these cold-water corals is a critical first step to understanding the ecosystem services their microbiomes contribute, while providing a benchmark against which to measure responses to environmental change or anthropogenic effects. Samples of Acanthogorgia aspera, A. spissa, Desmophyllum dianthus, and D. pertusum (Lophelia pertusa) were collected from western Atlantic sites off the US east coast and from the northeastern Gulf of Mexico. Microbiomes were characterized by $16 \mathrm{~S}$ rRNA gene amplicon surveys. Although $D$. dianthus and $D$. pertusum have recently been combined into a single genus due to their genetic similarity, their microbiomes were significantly different. The Acanthogorgia spp. were collected from submarine canyons in different regions, but their microbiomes were extremely similar and dominated by Endozoicomonas. This is the first report of coral microbiomes dominated by Endozoicomonas occurring below $1000 \mathrm{~m}$, at temperatures near $4^{\circ} \mathrm{C}$. D. pertusum from 2 Atlantic sites were also dominated by distinct Endozoicomonas, unlike $D$. pertusum from other sites described in previous studies, including the Gulf of Mexico, the Mediterranean Sea and a Norwegian fjord.

KEY WORDS: Coral $\cdot$ Deep-sea coral $\cdot$ Microbiome $\cdot$ Bacteria $\cdot$ Lophelia pertusa $\cdot$ Biodiversity

*Corresponding author: ckellogg@usgs.gov

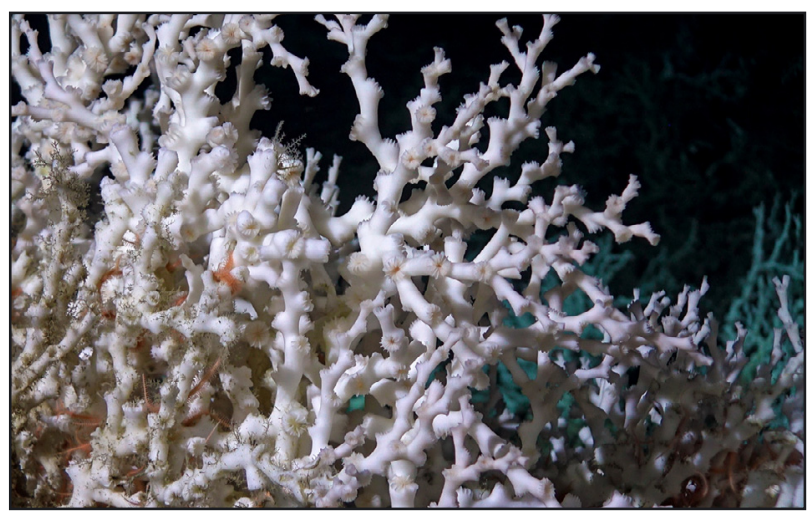

Microbiomes of deep-sea coral Desmophyllum pertusum (Lophelia pertusa) at Richardson Ridge are dominated by Endozoicomonas.

Photo: Erik Cordes, Chief Scientist of the DEEP SEARCH program, BOEM, USGS, NOAA OER. () Woods Hole Oceanographic Institution

\section{INTRODUCTION}

There are more species of corals in the deep ocean than there are in shallow waters (Roberts \& Hirshfield 2004, Roberts et al. 2009). This incredible diversity of cold-water corals, including both calcifying scleractinians and soft octocorals, serves a fundamental role in creating 3-dimensional structure in the deep sea (Roberts et al. 2006). This structure provides the foundation for biodiversity hot spots that support a large variety of invertebrates as well as economically important fish species (Buhl-Mortensen \& Mortensen 2004, 2005, Stone 2006, Cordes et al. 2008). However, the technical difficulty and expense

(C) Z. Pratte and outside the USA The U.S. Government 2021. Open Access under Creative Commons by Attribution Licence. Use, distribution and reproduction are unrestricted. Authors and original publication must be credited.

Publisher: Inter-Research · www.int-res.com 
of accessing this environment means that relatively little is known about these cold-water coral ecosystems and the basic biology of their keystone species, including age, growth rates, reproduction, and microbiome compositions.

Cold-water corals are azooxanthellate (Stanley \& Cairns 1988) and therefore their prokaryotic symbionts are hypothesized to play an even larger role in nutrient cycling and waste management than prokaryotic symbionts do in the nutrition of zooxanthellate corals (Neulinger et al. 2008, Kellogg 2019). The best microbially characterized cold-water coral is Desmophyllum pertusum (Lophelia pertusa), a complex mound-building species that is particularly abundant in the North Atlantic (Yakimov et al. 2006, Neulinger et al. 2008, 2009, Hansson et al. 2009, Kellogg et al. 2009, 2017, Schöttner et al. 2009, Galkiewicz et al. 2011, 2012, Weinbauer et al. 2012, van Bleijswijk et al. 2015, Meistertzheim et al. 2016, Chapron et al. 2020, Galand et al. 2020). The bacterial communities of a handful of other deep-sea scleractinian corals have also been characterized: Dendrophyllia sp. (Röthig et al. 2017b), Eguchipsammia fistula (Röthig et al. 2017a,b), Madrepora oculata (Hansson et al. 2009, Meistertzheim et al. 2016), and Rhizotrochus typus (Röthig et al. 2017b). More recently, baseline descriptions of the bacterial communities of a number of deep-sea octocorals have been published (Gray et al. 2011, Kellogg et al. 2016, Lawler et al. 2016, Goldsmith et al. 2018, Weiler et al. 2018).

While there have been increasing numbers of reports describing Endozoicomonas-dominated microbiomes in tropical scleractinian corals (Morrow et al. 2012, Speck \& Donachie 2012, Bayer et al. 2013b, Roder et al. 2015, Apprill et al. 2016, GignouxWolfsohn et al. 2017, Brener-Raffalli et al. 2018, Pogoreutz et al. 2018, Camp et al. 2020) as well as tropical and temperate octocorals (Bayer et al. 2013a, Vezzulli et al. 2013, van de Water et al. 2017, McCauley et al. 2020, Reigel et al. 2020), this bacterial genus has been notably scarce in deep-sea coldwater corals. An analysis that included 6 deep-sea octocoral species found Endozoicomonas to be rare in Anthothela spp. and undetectable in the other species (Kellogg 2019). An exception is M. oculata, whose microbiome is dominated by Endozoicomonas in both the Mediterranean and the Atlantic (Rockall Bank), although not by the same phylotypes (Hansson et al. 2009, Meistertzheim et al. 2016, Galand et al. 2018). These collections occurred over a depth range of 520 to $781 \mathrm{~m}$, with Atlantic site temperatures of $7.6-9.0^{\circ} \mathrm{C}$ and Mediterranean site temperatures of $\sim 13^{\circ} \mathrm{C}$. Further, the 3 studies that identified Endozoicomonas as dominating the $M$. oculata microbiome also examined $D$. pertusum collected from the same sites at the same time via the same methods and found few or no Endozoicomonas (Hansson et al. 2009, Meistertzheim et al. 2016, Galand et al. 2018). Prior studies of $D$. pertusum from the Mediterranean (Yakimov et al. 2006), a Norwegian fjord (Neulinger et al. 2008), Rockall Bank (van Bleijswijk et al. 2015), and Gulf of Mexico/western Atlantic (Kellogg et al. 2009, 2017, Galkiewicz et al. 2011) have either not detected Endozoicomonas or found it to be extremely rare $(<1.5 \%$ relative abundance).

Cataloging microbial baselines for cold-water coral species is a critical first step to understanding and predicting the ecosystem services their microbiomes contribute, as well as providing a benchmark against which to measure changes in response to environmental change or anthropogenic impacts. The specific objectives of this work were to (1) determine if microbiome data would corroborate the taxonomic amalgamation of $D$. dianthus and $D$. pertusum into a single genus; (2) compare corals that share a habitat type/depth zone in submarine canyons (D. dianthus, Acanthogorgia aspera, and A. spissa); and (3) establish benchmark bacterial community data for $D$. dianthus, A. aspera, and A. spissa. This resulted in the unexpected discovery that both Acanthogorgia spp. and some $D$. pertusum microbiomes were dominated by Endozoicomonas.

\section{MATERIALS AND METHODS}

\subsection{Sample sites and collections}

Deep-sea coral samples were collected for microbial analysis during 4 research cruises between the years 2013 and 2019 via a combination of crewed undersea vehicles and remotely operated vehicles (ROVs) (Table 1, Fig. 1). Samples from Norfolk Canyon were collected in 2013 on the NOAA ship 'Ronald H. Brown' using the ROV 'Jason II' (RB-13-03-HBH Deepwater Canyons). Samples from the West Florida sites Many Mounds and Okeanos Ridge were collected in 2017 on the NOAA ship 'Nancy Foster' using the ROV 'Odysseus' (NF1708 Southeast Florida Deep Coral Initiative). The 2018 and 2019 collections were part of the DEEP SEARCH program and were conducted on the RV 'Atlantis' using the humanoccupied vehicle (HOV) 'Alvin' (AT41) and the NOAA ship 'Ronald H. Brown' using the ROV 'Jason II' (RB1903), respectively. 
Table 1. Sample collection sites and associated environmental data for coral collections. ND: not determined; dates are given as $\mathrm{mo} / \mathrm{d} / \mathrm{yr}$

\begin{tabular}{|c|c|c|c|c|c|c|c|c|}
\hline Coral & Site & Sample ID & Date & $\begin{array}{c}\text { Depth } \\
\text { (m) }\end{array}$ & $\begin{array}{l}\text { Latitude } \\
\quad\left({ }^{\circ} \mathrm{N}\right)\end{array}$ & $\begin{array}{c}\text { Longitude } \\
\left({ }^{\circ} \mathrm{W}\right)\end{array}$ & $\begin{array}{c}\text { Temp } \\
\left({ }^{\circ} \mathrm{C}\right)\end{array}$ & Salinity \\
\hline Acanthogorgia aspera & Norfolk Canyon & $685 Q 2^{\mathrm{a}}$ & $5 / 11 / 13$ & 1328 & 37.04984 & 74.51377 & 4.1 & 35.0 \\
\hline Acanthogorgia aspera & Norfolk Canyon & 685Q3 & $5 / 11 / 13$ & 1336 & 37.04989 & 74.51357 & 4.2 & 35.0 \\
\hline Acanthogorgia aspera & Norfolk Canyon & $685 Q 4^{\mathrm{a}}$ & $5 / 11 / 13$ & 1312 & 37.05002 & 74.51246 & 4.1 & 35.0 \\
\hline Acanthogorgia aspera & Norfolk Canyon & 685Q5 & $5 / 11 / 13$ & 1311 & 37.04991 & 74.51234 & 4.2 & 35.0 \\
\hline Acanthogorgia aspera & Cape Lookout & RB1903-J2-1135-Q3 ${ }^{a}$ & $4 / 25 / 19$ & 944 & 33.91891 & 75.83344 & 4.5 & 35.0 \\
\hline Acanthogorgia spissa & Pamlico Canyon & RB1903-J2-1132-Q1 & $4 / 22 / 19$ & 1476 & 34.93145 & 75.15013 & 3.9 & 35.0 \\
\hline Acanthogorgia spissa & Pamlico Canyon & RB1903-J2-1132-Q2 & $4 / 22 / 19$ & 1476 & 34.93145 & 75.15013 & 3.9 & 35.0 \\
\hline Acanthogorgia spissa & Pamlico Canyon & RB1903-J2-1132-Q5 & $4 / 22 / 19$ & 1476 & 34.93145 & 75.15013 & 3.9 & 35.0 \\
\hline Acanthogorgia spissa & Pamlico Canyon & RB1903-J2-1132-Q6 & $4 / 22 / 19$ & 1402 & 34.93160 & 75.15148 & 4.0 & 35.0 \\
\hline Desmophyllum dianthus & Blake Escarpment & AT41-A4964-Q1 & $8 / 25 / 18$ & 1216 & 31.32269 & 77.24234 & 4.3 & 35.0 \\
\hline Desmophyllum dianthus & Blake Deep & RB1903-J2-1131-Q4 & $4 / 18 / 19$ & 1321 & 31.28760 & 77.23677 & 4.1 & 35.0 \\
\hline Desmophyllum dianthus & Blake Deep & RB1903-J2-1131-Q6 & $4 / 18 / 19$ & 1320 & 31.28767 & 77.23660 & 4.2 & 35.0 \\
\hline Desmophyllum dianthus & Blake Deep & RB1903-J2-1131-Q8 & $4 / 18 / 19$ & 1321 & 31.28762 & 77.23677 & 4.1 & 35.0 \\
\hline Desmophyllum dianthus & Pamlico Canyon & RB1903-J2-1132-Q3 & $4 / 22 / 19$ & 1567 & 34.93077 & 75.15035 & 3.9 & 35.0 \\
\hline Desmophyllum dianthus & Pamlico Canyon & RB1903-J2-1132-Q4 & $4 / 22 / 19$ & 1567 & 34.93077 & 75.15035 & 3.9 & 35.0 \\
\hline Desmophyllum dianthus & Pamlico Canyon & RB1903-J2-1132-Q8 & $4 / 22 / 19$ & 1567 & 34.93077 & 75.15035 & 3.9 & 35.0 \\
\hline Desmophyllum pertusum & Richardson Ridge & AT41-A4962-Q2 & $8 / 23 / 18$ & 695 & 32.00998 & 77.39507 & 9.2 & 35.2 \\
\hline Desmophyllum pertusum & Richardson Ridge & AT41-A4963-Q2 & $8 / 24 / 18$ & 827 & 31.98494 & 77.41471 & 5.0 & 35.1 \\
\hline Desmophyllum pertusum & Richardson Ridge & AT41-A4963-Q3 & $8 / 24 / 18$ & 789 & 31.98449 & 77.41393 & 6.8 & 35.1 \\
\hline Desmophyllum pertusum & Richardson Ridge & AT41-A4963-Q8 & 8/24/18 & 684 & 31.98459 & 77.41106 & 10.9 & 35.4 \\
\hline Desmophyllum pertusum & Richardson Ridge & AT41-A4963-Q10 & $8 / 24 / 18$ & 685 & 31.98450 & 77.41122 & 10.9 & 35.4 \\
\hline Desmophyllum pertusum & Cape Fear Coral & AT41-A4968-Q1 & $8 / 29 / 18$ & 381 & 33.57256 & 76.46505 & 7.0 & 35.5 \\
\hline Desmophyllum pertusum & Cape Fear Coral & AT41-A4968-Q2 & 8/29/18 & 460 & 33.57551 & 76.46792 & 7.7 & 35.2 \\
\hline Desmophyllum pertusum & Pea Island Seep & RB1903-J2-1133-Q3 & $4 / 23 / 19$ & 296 & 34.67360 & 75.79777 & 11.4 & 35.5 \\
\hline Desmophyllum pertusum & Many Mounds & NF1708-10-01 & $8 / 19 / 17$ & 480 & 26.20755 & 84.72610 & ND & ND \\
\hline Desmophyllum pertusum & Many Mounds & NF1708-10-08 & $8 / 19 / 17$ & 496 & 26.20576 & 84.72679 & ND & ND \\
\hline Desmophyllum pertusum & Many Mounds & NF1708-11-04 & $8 / 19 / 17$ & 432 & 26.20725 & 84.71101 & ND & ND \\
\hline Desmophyllum pertusum & Okeanos Ridge & NF1708-12-01 & $8 / 20 / 17$ & 521 & 25.66988 & 84.58431 & 7.1 & 35.0 \\
\hline
\end{tabular}

Five Acanthogorgia aspera were collected from Norfolk Canyon. These small yellow gorgonians were commonly encountered in this canyon and were collected along a long steep wall. Finding $A$. aspera in Norfolk Canyon was a northward range extension for this species because it was previously only known from the Gulf of Mexico and south of Cape Hatteras (Brooke et al. 2017). The A. aspera collected from Cape Lookout was growing on a boulder in an area of scattered boulders with a few coral colonies growing on them, including bamboo and black corals. $A$. spissa occurring in Pamlico Canyon were collected along the northern steep canyon wall from terrace overhangs commonly also populated by Desmophyllum dianthus. With the exception of the Cape Lookout collection at $944 \mathrm{~m}$ depth, Acanthogorgia spp. were collected below $1300 \mathrm{~m}$ (Table 1).

The D. dianthus colony from Blake Escarpment was growing on the skeleton of a dead bamboo coral. The 3 D. dianthus collected at Blake Deep were from a rock overhang at the top of a ridge, also populated by anemones, Anthomastus sp., black coral, and bamboo corals. Pamlico Canyon $D$. dianthus colonies were also from a ledge underhang community, likewise populated by Solenosmilia variabilis, Acanthogorgia sp., and brisingid sea stars. These solitary cup corals were all collected below 1200 m (Table 1).

The Richardson Ridge site is part of a $D$. pertusum mound complex that covers an area over $100 \mathrm{~km}^{2}$ (Stetson et al. 1962). This large area of linear mounds of D. pertusum exists below the Gulf Stream (Stetson et al. 1962, Legeckis 1979, Popenoe 1994), deeper than most $D$. pertusum habitats known for this area (Table 1), and is subject to high current speeds. Corals in this area experience a variable temperature range (Table 1). The Cape Fear coral mound site was also subject to strong currents and can be impacted by Gulf Stream meanders (Bane \& Brooks 1979). A single colony of $D$. pertusum was found growing at the shallow Pea Island seep site on authigenic carbonate substrate. The Gulf of Mexico/West Florida Slope collections of $D$. pertusum were conducted at 2 sites: Many Mounds and Okeanos Ridge (Fig. 1). The Many Mounds site was characterized by dense ag- 


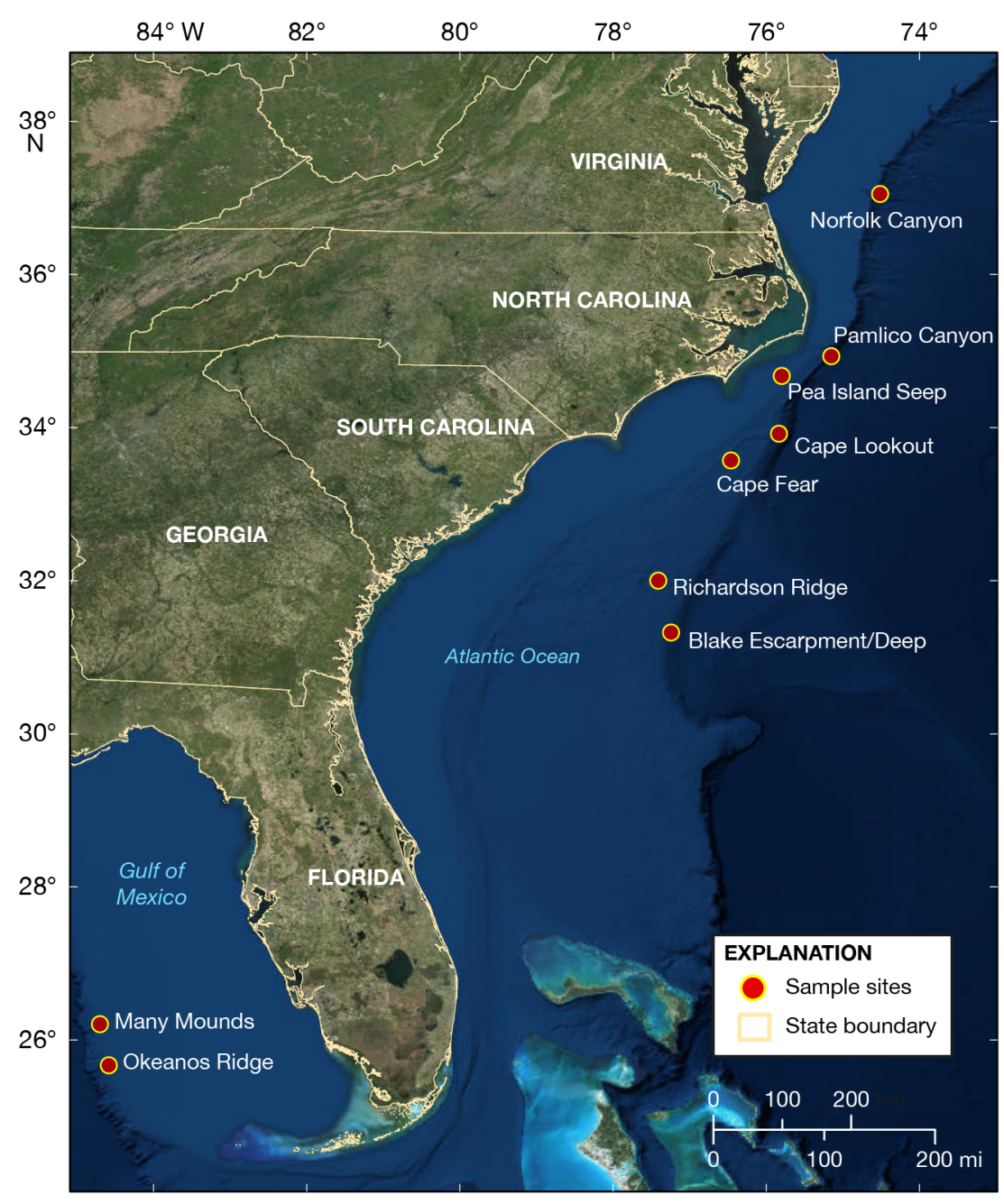

Fig. 1. Sampling site locations. See Table 1 for additional sampling site metadata. Base-map credit: Esri, DigitalGlobe, GeoEye, Earthstar Geographics, CNES/ Airbus DS, USDA, USGS, AeroGRID, IGN, and the GIS User Community

gregations of $D$. pertusum mixed with scattered sponges, soft corals and octocorals (Ross et al. 2017). Western Atlantic and Gulf of Mexico D. pertusum colonies are predominantly the white color morph; however, sample NF1708-10-08 was a rare orange colony. The Okeanos Ridge D. pertusum was collected from a wall slope.

Subsamples of coral colonies were collected using the respective vehicle's manipulator arm to remove a branch (or in the case of $D$. dianthus, the entire cup coral). Samples were placed into individual, thermally insulated containers that had been precleaned (washed with freshwater, interiors wiped with $100 \%$ ethanol to remove any biofilms or particulates from prior collections), filled with freshwater, and sent down sealed. When opened to receive a coral collection, the freshwater was replaced by seawater local to the collection site due to density differences. The containers were then sealed at depth to prevent microbial contamination from other sample collections or passing through different water masses during vehicle recovery. At the conclusion of the dive, containers were brought into a cold room or laboratory and samples were removed using ethanol-sterilized forceps. All corals were lightly rinsed with sterile $1 \times$ phosphate-buffered saline (PBS) to remove any loosely associated surface microbes. For octocorals (A. aspera, A. spissa), branches that had not been in contact with the manipulator claw were cut off using ethanol-sterilized shears and transferred to sterile tubes. For the stony corals (D. dianthus, $D$. pertusum), samples were placed into sterile aluminum weigh boats and a flame-sterilized hammer was used to break open the calyces to expose polyp tissue, which was transferred to sterile tubes. All samples were preserved with RNAlater (Invitrogen), stored for $24 \mathrm{~h}$ at $4^{\circ} \mathrm{C}$ to allow the preservative to infiltrate the tissues, and then moved to $-20^{\circ} \mathrm{C}$ until processing. Subsamples of the corals collected for microbial analyses were shared with researchers conducting population genetics/taxonomy studies, allowing for accurate host identification of octocorals and the possibility of interpreting microbiome trends against coral genotypes (Goldsmith et al. 2018).

\subsection{Nucleic acid extraction and sequencing}

Prior to extraction, coral samples were rinsed with $0.2 \mu \mathrm{m}$-filtered and autoclaved $1 \times$ PBS to remove excess salts from RNAlater (Invitrogen). Coral pieces were placed into sterile microcentrifuge tubes using flame-sterilized forceps, $2 \mathrm{ml}$ of the sterile $1 \times$ PBS was added to the tube, which was then inverted 3 times and then centrifuged at $4000 \times g(30 \mathrm{~s})$. The coral samples were then weighed using a sterile technique and approximately 0.1-0.2 g sample $\mathrm{g}^{-1}$ were used for extraction. Extractions were done in duplicate for each coral using the DNeasy PowerBiofilm kit (Qiagen), and replicates were combined after the final step. The manufacturer's protocol was followed with the exception that a FastPrep (MP Biomedicals) was 
used on setting 5 ( $3100 \mathrm{rpm}$ ) for homogenization in place of a PowerLyzer (Qiagen). Kit blanks (extractions with no sample added) were processed at the same time as the samples. DNA was quantified using a Qubit dsDNA High Sensitivity (HS) assay (Invitrogen), and extractions were diluted to approximately $30 \mathrm{ng} \mathrm{l}^{-1}$, and submitted for sequencing.

Polymerase chain reaction (PCR) amplification and sequencing were performed by the RTSF Genomics Core at Michigan State University. The V3-V4 regions of the 16S rRNA gene were amplified with the primers 341F (5'-CCT ACG GGA GGC AGC AG-3') (Herlemann et al. 2011) and 806R (5'-GGA CTA CHV GGG TWT CTA AT-3') (Caporaso et al. 2011). One $\mu \mathrm{l}$ of genomic DNA was added to $7.5 \mu \mathrm{l}$ of $2 \times$ Dream Taq Master Mix (Thermo Scientific) and $6.4 \mu \mathrm{l}$ of a $0.5 \mu \mathrm{M}$ primer mix. Amplification conditions were an initial melting period of $2 \mathrm{~min}$ at $95^{\circ} \mathrm{C}$, followed by 30 cycles of $95^{\circ} \mathrm{C}$ for $40 \mathrm{~s}, 50^{\circ} \mathrm{C}$ for $30 \mathrm{~s}$, and $72^{\circ} \mathrm{C}$ for $60 \mathrm{~s}$, and a final anneal step at $72^{\circ} \mathrm{C}$ for $7 \mathrm{~min}$. After PCR, the output of all reactions was batch normalized using an Invitrogen SequalPrep DNA Normalization Plate, and all material recovered from the plate was pooled. The pooled material was cleaned up and concentrated using AmpureXP magnetic beads (Beckman Coulter Life Sciences). The pool was quality controlled and quantified using a combination of Qubit dsDNA HS, Agilent 4200 TapeStation HS DNA1000, and Kapa Illumina Library Quantification qPCR assays. After quality control, this pool was loaded onto an Illumina MiSeq v2 Standard flow cell, and sequencing was carried out in a $2 \times 250$ bp paired end format using a MiSeq v2 500 cycle reagent cartridge. Custom sequencing and index primers complementary to the $341 \mathrm{~F} / 806 \mathrm{R}$ sequences used for preparing the libraries were added to appropriate wells of the reagent cartridge. Base calling was done by Illumina Real Time Analysis (RTA) v1.18.54, and output of RTA was demultiplexed and converted to FastQ format with Illumina Bcl2fastq v2.19.1. Sequence data are available from the NCBI Sequence Read Archive (SRA) under BioProject number PRJNA699458 (submission SUB9027826) and are also available online as a US Geological Survey data release (https://doi.org/10.5066/P9Z1HPKR).

\subsection{Data curation and analysis}

Data were imported into QIIME2 (version 2020.8) and sorted into amplicon sequence variants (ASVs) using the DADA2 pipeline with the parameters: --ptrim-left-f 50 --p-trim-left-r 50 --p-trunc-len-f 225 and --p-trunc-len-r 225 (Callahan et al. 2016, Bolyen et al. 2019). Taxonomy was assigned with the SILVA reference database trained for the V3-V4 region (silva-138-99) (Quast et al. 2013). ASVs identifying as mitochondria, chloroplasts, or not assigned to the domains 'Bacteria' or 'Archaea' were removed. All samples were rarefied to 11778 sequences, removing 3 samples from the dataset that did not contain this number of sequences (Table 1). The QIIME2 diversity plugin was used to compute all alpha diversity metrics (observed ASVs, Shannon diversity index, Pielou's evenness, Faith's phylogenetic diversity) and a permutational multivariate ANOVA (PERMANOVA) for each alpha diversity metric (Shannon 1948, Kruskal \& Wallis 1952, Pielou 1966, Faith 1992, DeSantis et al. 2006). The QIIME2 diversity plugin was also used to calculate all beta diversity metrics (Bray-Curtis dissimilarity, Jaccard similarity index, and weighted and unweighted Unifrac distances) (Jaccard 1908, Bray \& Curtis 1957, Lozupone \& Knight 2005, Lozupone et al. 2007). For each beta diversity metric, an analysis of similarities (ANOSIM) and a resemblance-based permutation test (PERMDISP) were conducted (Clarke 1993, Anderson 2001, Anderson \& Walsh 2013). A second analysis was conducted with only those samples associated with scleractinian corals $(D$. dianthus and $D$. pertusum), including all diversity indices and statistical analyses listed above.

\subsection{Endozoicomonas analysis}

All sequences within the genus Endozoicomonas were identified for further analysis. Sequences were aligned in MEGA X (Kumar et al. 2018, Stecher et al. 2020) using ClustalW (Thompson et al. 1994), with the addition of relevant sequences from NCBI's SRA and Nucleotide databases. An evolutionary tree of the 20 most common Endozoicomonas sequences was constructed using the maximum likelihood method (Tamura \& Nei 1993), with a bootstrap value of 500 .

\section{RESULTS}

After quality control, the number of sequences per sample ranged from 494 to 722149 , with an average of 216210 and a standard deviation of \pm 216213 . After rarefaction to 11778 sequences, 3 samples were removed due to low numbers of sequences (Table 1), as was the extraction kit blank. 


\subsection{Alpha diversity metrics}

Desmophyllum dianthus had a significantly higher number of observed ASVs than D. pertusum and Acanthogorgia spissa, but not A. aspera (Fig. 2, Table 2), likely due to the small number of $A$. aspera samples that were successfully sequenced $(n=2)$. Although Shannon diversity and Pielou's evenness were not significantly different between species, Faith's phylogenetic diversity was significantly different when comparing $D$. dianthus to all other coral species (Table 2). When examined by site location, $D$.

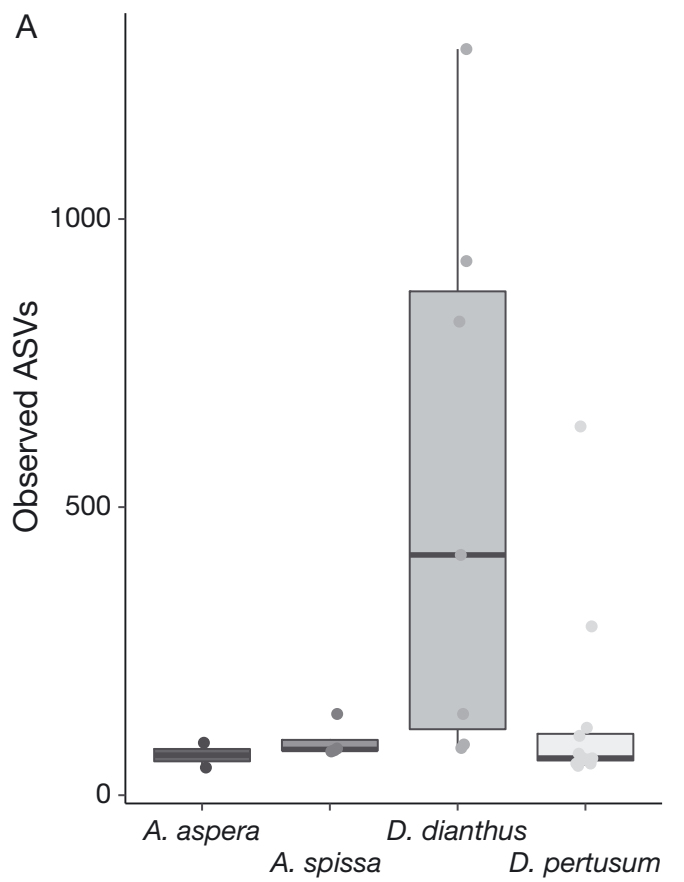

dianthus demonstrated higher numbers of observed sequences in 2 of the 3 locations (see Fig. S1 in the Supplement at www.int-res.com/articles/suppl/m673 p001_supp.pdf).

\subsection{Beta diversity metrics}

In a principal coordinate analysis (PCoA) based upon Bray-Curtis dissimilarities of all corals, there was a clear differentiation between the octocorals and scleractinians, in spite of Acanthogorgia spp. and

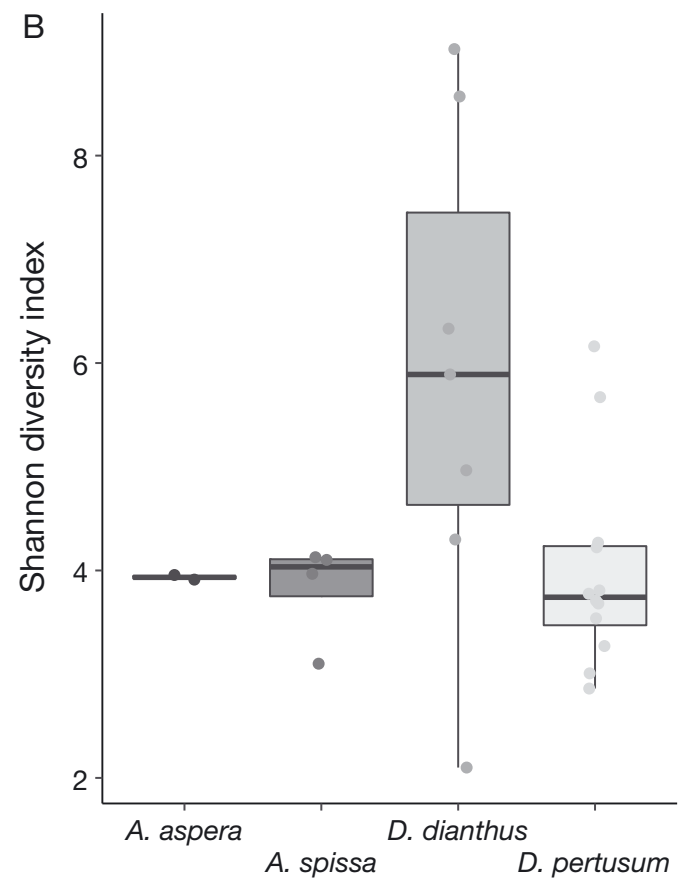

Coral species

Fig. 2. (A) Observed amplicon sequence variants (ASVs) and (B) Shannon diversity indices for Acanthogorgia aspera, A. spissa, Desmophyllum dianthus, and D. pertusum. All collection sites are pooled (see Fig. S1 for site-specific diversity metrics). Boxplots represent median, 25 to $75 \%$ interquartile range and non-outlier range; points beyond the whiskers are outliers

Table 2. Pairwise alpha and beta diversity statistics for Acanthogorgia aspera, A. spissa, Desmophyllum dianthus, and D. pertusum. The number of observed amplicon sequence variants (ASVs) and Faith's phylogenetic diversity were significantly different between species $(p=0.029$ and 0.017, respectively), while Shannon diversity and Pielou's evenness were not ( $p=0.114$ and 0.362, respectively), so no pairwise comparisons are given. Beta-diversity statistics are based upon Bray-Curtis dissimilarity. Both an analysis of similarities (ANOSIM; $p=0.001$, Global $r=0.74$ ) and dispersion (PERMDISP; $p=0.082$ ) were significantly different between species. All pairwise $\mathrm{p}$-values are adjusted, and significant values of $\mathrm{p}<0.1$ are indicated with *

\begin{tabular}{|c|c|c|c|c|c|c|}
\hline \multirow[t]{2}{*}{ Species 1} & \multirow[t]{2}{*}{ Species 2} & \multirow{2}{*}{$\begin{array}{c}\text { Observed ASVs } \\
\mathrm{p}\end{array}$} & \multirow{2}{*}{$\begin{array}{c}\text { Faith's phylogenetic diversity } \\
\text { p }\end{array}$} & \multicolumn{2}{|c|}{$\ldots$ ANOSIM } & \multirow{2}{*}{$\begin{array}{l}\text { PERMDISP } \\
p\end{array}$} \\
\hline & & & & $\mathrm{p}$ & $\mathrm{r}$ & \\
\hline A. aspera & A. spissa & 0.643 & 0.532 & 0.123 & 0.607 & 0.148 \\
\hline A. aspera & D. dianthus & 0.286 & $0.081^{*}$ & $0.040^{*}$ & 0.964 & 0.355 \\
\hline A. aspera & D. pertusum & 0.557 & 0.855 & $0.030^{*}$ & 0.979 & 0.346 \\
\hline A. spissa & D. dianthus & $0.088^{*}$ & $0.042^{*}$ & $0.002^{*}$ & 0.778 & $0.024^{*}$ \\
\hline A. spissa & D. pertusum & 0.337 & 0.628 & $0.002^{*}$ & 0.865 & $0.036^{*}$ \\
\hline D. dianthus & D. pertusum & $0.052^{*}$ & $0.007^{*}$ & $0.002^{*}$ & 0.648 & 0.346 \\
\hline
\end{tabular}


D. dianthus having been collected from similar habitats and depths. Both Acanthogorgia species clustered tightly together with the exception of 1 sample from Norfolk Canyon that still clustered relatively close (Fig. 3A). Three groupings of $D$. pertusum were observed, one of which clustered tightly with $D$. dianthus. Similar patterns were seen according to Jaccard similarity indices and unweighted Unifrac distances, but not weighted Unifrac distances (Fig. S2). This indicates that the observed patterns are driven by the equal importance of shared rare and dominant microbial taxa, rather than by abundance (dominance) of specific taxa. While Bray-Curtis does factor in abundance, it weights the abundance of shared species more, which explains the tighter clustering of Acanthogorgia spp. in Fig. 3A compared to the clusters in Fig. S2. Upon the independent analysis of $D$. pertusum and $D$. dianthus, each species clustered separately except for 1 sample from each species (Fig. 3B). In this analysis, $D$. pertusum samples collected from the Gulf of Mexico sites (Many Mounds and Okeanos Ridge) also clustered apart from other D. pertusum samples.

Microbial community structure (ANOSIM) and dispersion (PERMDISP) were analyzed between all coral species using Bray-Curtis dissimilarities. Dispersion was only significantly different between $A$. spissa and each scleractinian coral (D. pertusum and $D$. dianthus; Table 2). Microbial community structure was significantly different between all coral species except for A. aspera and A. spissa, with the high rvalues indicating that the communities were very distinct between species (Table 2).

\subsection{Community and Endozoicomonas analysis}

Community analysis at the class level indicated a substantial percentage of Gammaproteobacteria (Fig. S3). Upon further taxonomic evaluation, the majority of these Gammaproteobacteria were unexpected Endozoicomonas spp. Richardson Ridge and Cape Fear D. pertusum were dominated (13-88\%) by ASVs belonging to the genus Endozoicomonas, while those collected from other sites had very few (0-3\%) Endozoicomonas (Fig. 4). Microbial communities from $D$. dianthus did not contain more than $0.13 \%$ Endozoicomonas ASVs for any of the sampling sites. Both Acanthogorgia species also contained a large proportion of Endozoicomonas ASVs,
A All coral species

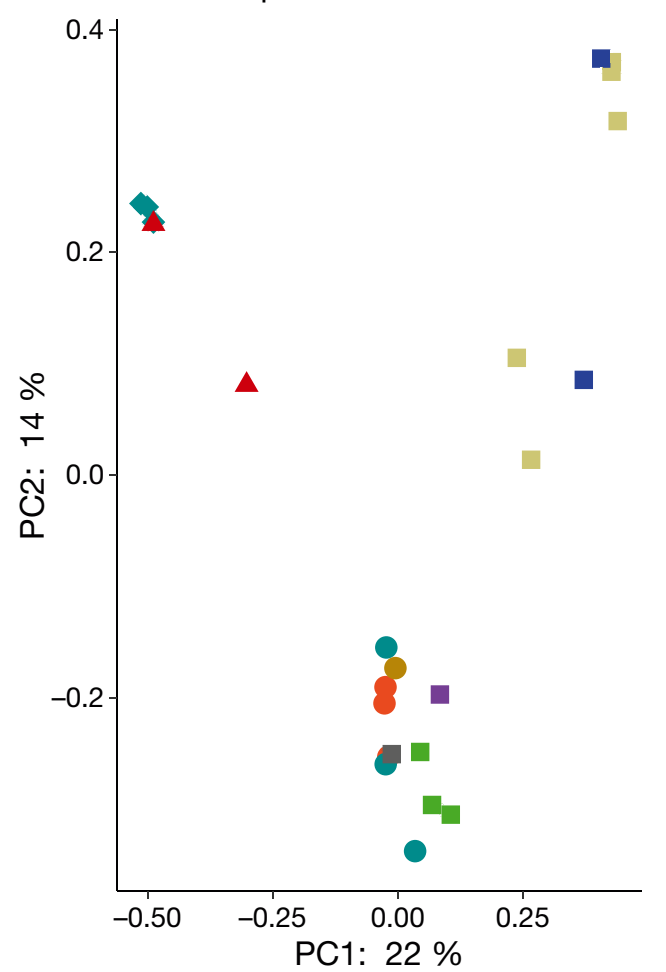

B Scleractinian corals

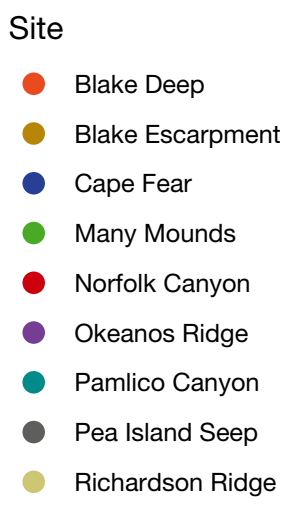

Coral Species

- Desmophyllum dianthus

- Desmophyllum pertusum

- Acanthogorgia aspera

- Acanthogorgia spissa

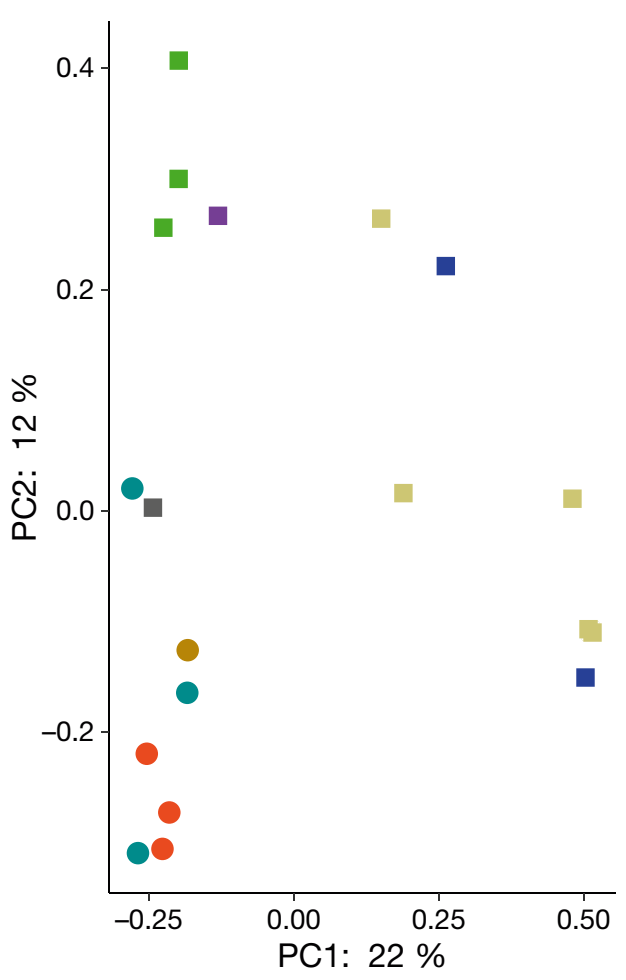

Fig. 3. Principal coordinates analysis (PCoA) based upon a Bray-Curtis dissimilarity matrix for 4 deep-sea coral species collected from 9 different sites. (A) All coral species; (B) only scleractinian coral species (Bray-Curtis dissimilarity matrices were calculated independently) 


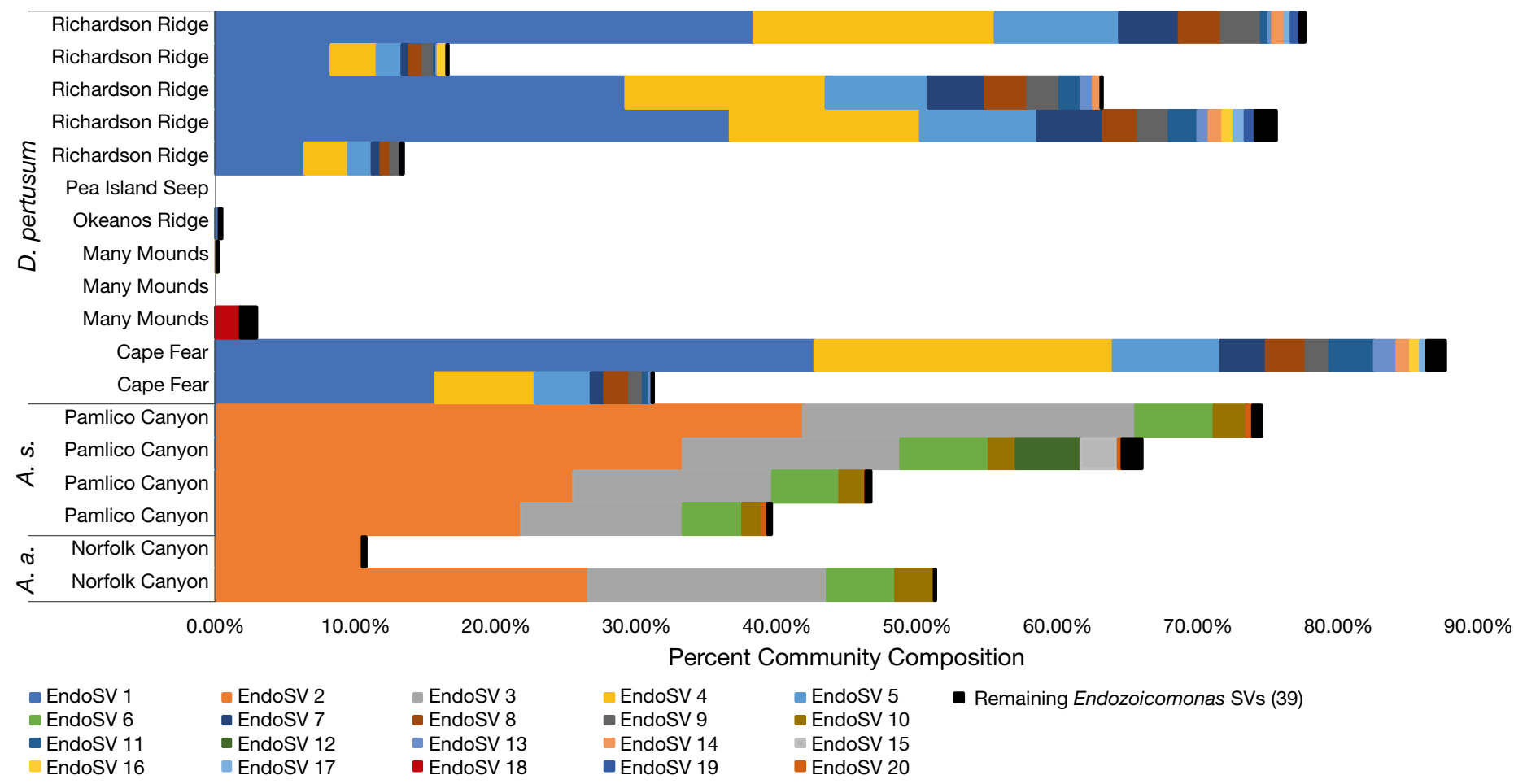

Fig. 4. Percent community composition of all Endozoicomonas amplicon sequence variants (ASVs) for 3 deep-water coral species: Acanthogorgia aspera (A.a.), A. spissa (A.s.), and Desmophyllum pertusum. The top 20 most abundant ASVs are given independently, with the remaining 39 combined

ranging from 11 to $75 \%$ (Fig. 4). Interestingly, the 2 Acanthogorgia species shared many Endozoicomonas ASVs, despite being collected from different regions. A phylogenetic tree was created to determine phylogenetic relatedness of the Endozoicomonas ASVs. The Endozoicomonas ASVs clustered into 2 main branches, those from $D$. pertusum and those from both Acanthogorgia species (Fig. 5).

\section{DISCUSSION}

Compared to tropical or even temperate corals, there have been relatively few microbiome studies of cold-water corals from the deep ocean. Deep-sea octocoral microbiomes show variation in their most abundant taxa: Paragorgia arborea is dominated by Tenericutes (Weiler et al. 2018), Anthothela grandiflora is dominated by a combination of Gammaproteobacteria and Spirochaetes (Lawler et al. 2016), Primnoa resedaeformis and Paramuricea placomus are both dominated by Proteobacteria, but vary in whether Alpha- or Gammaproteobacteria are more abundant (Kellogg et al. 2016, Goldsmith et al. 2018). In contrast, deep-sea stony corals including Eguchipsammia fistula in the Red Sea, and Desmophyllum pertusum and Madrepora oculata in the Mediterranean, all are dominated by Gammaproteobacteria (Meistertzheim et al. 2016, Röthig et al. 2017b). We found both Acanthogorgia spp., as well as D. pertusum, to be dominated by Gammaproteobacteria, but $D$. dianthus had a variable mixture of Alpha- and Gammaproteobacteria (Fig. S3).

\subsection{Dissimilarity between $D$. dianthus and D. pertusum microbiomes}

The bacterial communities associated with cup coral $D$. dianthus had significantly more variability and richness compared to the community associated with $D$. pertusum (Fig. 2, Fig. S1). While a few colonies of the 2 species grouped together (Fig. 3, Fig. S2), the 2 species hosted significantly different microbiomes (Table 2, Fig. S3). Interestingly, the single $D$. pertusum sample from the Pea Island Seep site, which might be predicted to have an unusual microbiome due to the shallow depth, relatively high temperature $\left(11.4^{\circ} \mathrm{C}\right)$, and influence of seep conditions, was both an outlier from the other $D$. pertusum samples and closest to $D$. dianthus samples (Fig. 3). 


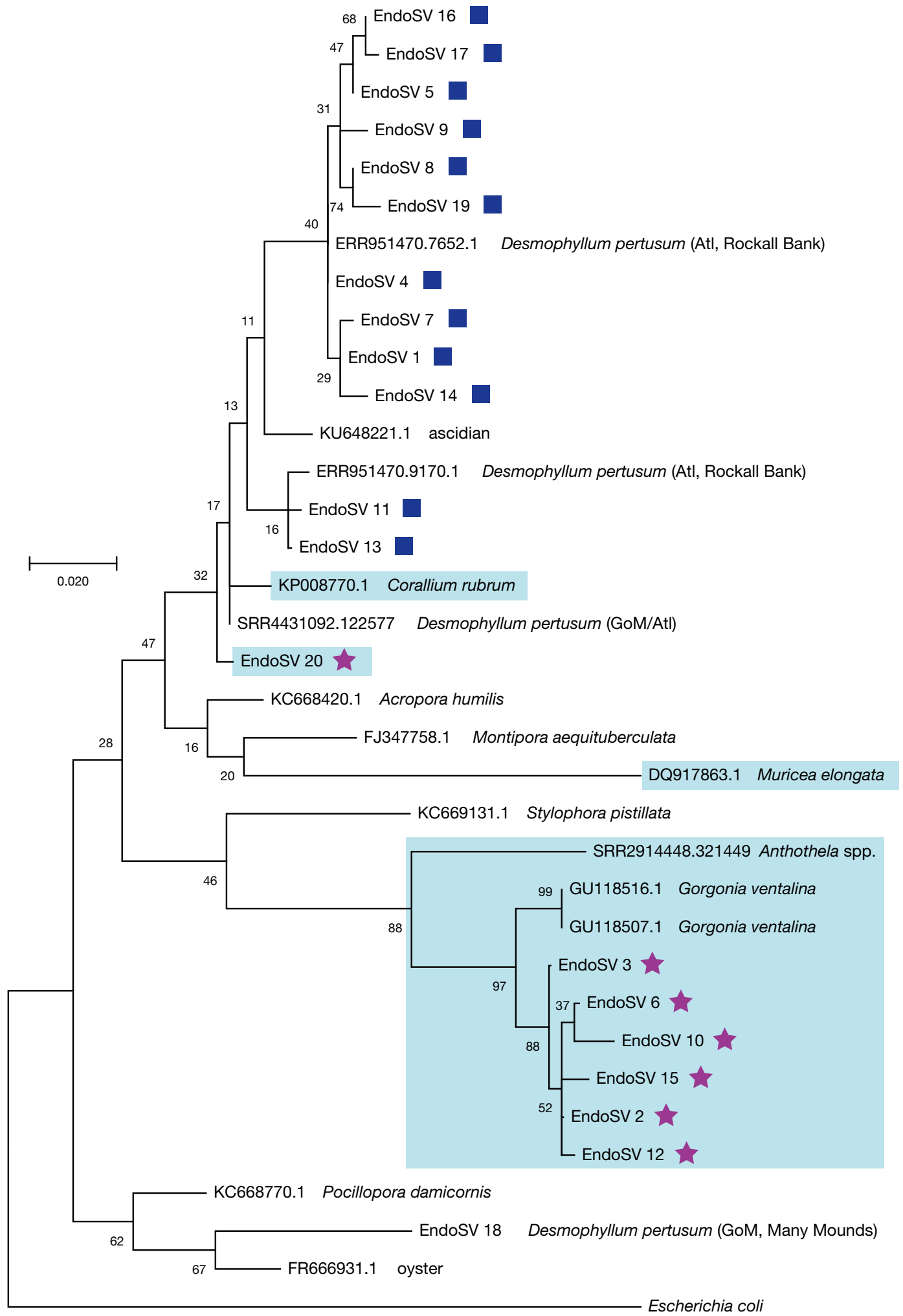

Fig. 5. Maximum likelihood evolutionary tree of the top 20 most abundant Endozoicomonas amplicon sequence variants (EndoSV 1-20) detected in Acanthogorgia spp. and Desmophyllum pertusum with similar sequences from the NCBI nucleotide (https://www.ncbi.nlm.nih.gov/nuccore) or sequence read archive (SRA) databases (https://trace.ncbi.nlm.nih.gov/Traces/sra/) (accession numbers are shown). Bootstrap values are given at each node (500 repetitions). Escherichia coli was used as an outgroup. Blue squares indicate Endozoicomonas amplicon sequence variants only found in $D$. pertusum samples from Richardson Ridge and Cape Fear sites. Purple stars indicate Endozoicomonas amplicon sequence variants only found in Acanthogorgia spp. samples. Aqua boxes indicate Endozoicomonas genotypes identified from octocorals. Atl: Atlantic; GoM: Gulf of Mexico 
There was some expectation that $D$. dianthus and D. pertusum might have similar microbiomes because the 2 corals have been reclassified into a single genus based on genetic similarity (Addamo et al. 2016). Prior work on tropical scleractinians has shown conservation of bacterial communities at the genus level (Littman et al. 2009) or that coral microbiome composition tracks host phylogeny (Sunagawa et al. 2010, Pollock et al. 2018). However, we typically encountered these 2 corals in different depth zones (Table 1) and different habitats, which likely has some influence on their microbiomes (Pantos et al. 2015, Hernandez-Agreda et al. 2016). Moreover, recent research on $D$. pertusum has indicated that diet may have a strong influence on the microbiome (Galand et al. 2020) and a comparison between D. pertusum and $D$. dianthus showed differences in ingestion rates of different sized prey (Tsounis et al. 2010).

An additional hypothesis to consider is that of differing 'microbiome flexibility' between $D$. pertusum and D. dianthus (Ziegler et al. 2019). A reciprocal transplant experiment with 2 tropical stony corals found that one (Acropora hemprichii) had a flexible microbiome that varied between experimental sites, while the other (Pocillopora verrucosa) maintained a stable microbiome, indicating the existence of different host-microbiome adaptation strategies (Ziegler et al. 2019, Voolstra \& Ziegler 2020). In the Mediterranean, microbiome comparisons between D. pertusum and $M$. oculata revealed that the microbiome of $M$. oculata was stable across seasons and during a reciprocal transplant experiment, while that of $D$. pertusum was more clearly influenced by environmental conditions (Meistertzheim et al. 2016, Chapron et al. 2020). Further, multiple prior studies of D. pertusum have provided evidence that the bacterial community of this coral exhibits variability across different geographic sites (Neulinger et al. 2008, Kel$\log$ et al. 2009, 2017, Schöttner et al. 2009) and the clustering patterns observed in our current study are consistent with $D$. pertusum having a more flexible microbiome than D. dianthus (Fig. 3B).

\subsection{Similarity between Acanthogorgia spp. microbiomes}

In contrast, the microbiomes of the 2 Acanthogorgia species clustered very tightly, with 1 exception, and were not statistically distinguishable (Fig. 3, Table 2). With the exception of 1 Norfolk Canyon $A$. aspera, the Acanthogorgia spp. microbiomes were dominated (40-75\%) by Endozoicomonas (Fig. 4).
Conserved core ASVs (present in all 6 samples analyzed) included 2 Endozoicomonas phylotypes and 4 Shewanella phylotypes. The $2 A$. aspera samples had higher relative abundance of class Bacteroidia compared to A. spissa (Fig. S3). Previous work found that the microbiomes of 2 species of the cold-water octocoral genus Anthothela also clustered together and were statistically indistinguishable (Lawler et al. 2016). The only prior knowledge for Acanthogorgiaassociated bacteria comes from a study that screened a variety of deep-sea corals in the Gulf of Mexico for the presence of chemoautotrophic bacteria from the SUP05 cluster (Vohsen et al. preprint https://www. biorxiv.org/content/10.1101/2020.02.27.968453v1). That study detected genus-specific SUP05 phylotypes at high abundance ( $>10 \%$ relative abundance) in A. aspera using primers that targeted the V1-V2 region of the 16S rRNA gene (Vohsen et al. preprint https://www.biorxiv.org/content/10.1101/2020.02.27. 968453v1). We detected 2 SUP05 cluster phylotypes at low abundance in our A. spissa samples but not in any of the $A$. aspera samples. This could be a methodological issue (i.e. differential detection by V3-V4 primers compared to V1-V2) or a biogeographic difference between microbiomes of Atlantic corals and Gulf of Mexico corals. In support of it being a biogeographic difference, we detected 3 SUP05 cluster phylotypes occurring in 4 to $6 \mathrm{D}$. pertusum samples: 1 phylotype was only present in Gulf of Mexico samples (Many Mounds and Okeanos Ridge), and the other 2 had higher numbers of sequence reads in Gulf of Mexico samples compared to Atlantic samples (Cape Fear and Richardson Ridge).

\subsection{Dominance of Endozoicomonas in} Acanthogorgia spp. and site-specific $D$. pertusum

There were clear differences between the Endozoicomonas community in $D$. pertusum compared to Acanthogorgia spp. (Figs. 4 \& 5). Host-specificity of Endozoicomonas genotypes has been observed in both shallow-water scleractinians and octocorals (Lee et al. 2012, La Rivière et al. 2015, Neave et al. 2017b, van de Water et al. 2017). There was substantial overlap of Endozoicomonas genotypes between $A$. aspera and $A$. spissa (as has been seen in sister species of Eunicella (van de Water et al. 2017)); however, EndoSV 20 was only present in A. spissa samples (Fig. 4). Studies of Mediterranean octocorals found evidence of codivergence between Endozoicomonas genotypes and their hosts (La Rivière et al. 2015, van de Water et al. 2017). Examination of rare Endozoico- 
monas genotypes from $D$. pertusum and Anthothela spp. found that they clustered with scleractinian and octocoral sequences, respectively, further suggesting influence of host phylogeny (Pollock et al. 2018, Kellogg 2019). In this study, all but one of the major Endozoicomonas genotypes from Acanthogorgia spp. formed a clade that clustered closely with other octocorals, Gorgonia ventalina and Anthothela spp. (Fig. 5). One rare genotype $(0.09-0.42 \%$ in A. spissa samples), EndoSV 20, fell outside the main octocoral cluster (Fig. 5). This variation may be evidence of the influence of both the control and local adaptation of the host (Neave et al. 2016).

A biogeographic study of Endozoicomonas genotypes in the widely distributed coral species Stylophora pistillata and $P$. verrucosa found that $S$. pistillata had geographically distinct Endozoicomonas communities (Neave et al. 2017b), similar to what we observed here in $D$. pertusum. The Endozoicomonas genotypes from $D$. pertusum at Richardson Ridge and Cape Fear sites formed 2 main clades, each including a sequence from $D$. pertusum from Rockall Bank (van Bleijswijk et al. 2015), on the eastern side of the Atlantic (Fig. 5). These groups were separate from an Endozoicomonas genotype that was detected in $D$. pertusum samples from multiple Gulf of Mexico sites as well as a western Atlantic site off Cape Canaveral, Florida (Kellogg et al. 2017) and from EndoSV 18 from D. pertusum in the Gulf of Mexico, the Many Mounds site (Fig. 5). In the case of $S$. pistillata and P. verrucosa, Neave et al. (2017b) hypothesized that the difference could be due to reproductive strategy; as a brooder, $S$. pistillata could more strictly control its microbiome by vertical transmission, resulting in geographic structuring. This hypothesis does not hold for $D$. pertusum, which is a broadcast spawner (Brooke \& Järnegren 2013). However, there is prior evidence for differentiation of $D$. pertusum microbiomes based on geographic region, including differences between the Gulf of Mexico and western Atlantic (Neulinger et al. 2008, Kellogg et al. 2017).

\subsection{What is driving the unusual $D$. pertusum microbiomes at Richardson Ridge/Cape Fear sites?}

Shallow-water studies of both scleractinians and octocorals suggest that reductions of Endozoicomonas abundance in hosts that are typically dominated by them are linked to unfavorable environmental conditions, such as excessive nutrients, temperature stress (hot or cold), or lower pH (Vezzulli et al. 2013,
Morrow et al. 2015, Roder et al. 2015, Neave et al. 2016, van de Water et al. 2017, Maher et al. 2019, Ziegler et al. 2019, Shiu et al. 2020). However, we do not know of any prior examples where coral microbiomes that typically do not host large numbers of Endozoicomonas have been found to shift to being dominated by them. In general, environmental disturbances that affect the metabolism and physiology of the coral host also change the microbiome (Vega Thurber et al. 2009, Lee et al. 2017). However, as mentioned in Section 4.1, the amount of 'microbiome flexibility' or restructuring of the bacterial composition under environmental change varies depending on the coral host (Ziegler et al. 2019). This microbiome flexibility is hypothesized to be a rapid adaptation that provides the coral host with a more beneficial bacterial community to improve coral fitness under the new conditions (Reshef et al. 2006, Voolstra \& Ziegler 2020). The Richardson Ridge and Cape Fear sites on the Blake Plateau are affected by the Gulf Stream (Stetson et al. 1962, Bane \& Brooks 1979, Legeckis 1979, Popenoe 1994), which can translate into extreme variability in water temperature, salinity, nutrients, and current speeds (e.g. Mienis et al. 2014). These factors have been shown to affect coral microbiomes in tropical systems (Guppy \& Bythell 2006, Littman et al. 2009, Zaneveld et al. 2016, Lee et al. 2017). The species makeup of a microbial community following disturbance may be explained by the environmental preferences and competitive abilities of the particular microbes (Maher et al. 2019, Ziegler et al. 2019). However, the majority of coral-associated Endozoicomonas appear to be sensitive to temperature stress outside the optimal range of $15-30^{\circ} \mathrm{C}$ (Kellogg 2019, Shiu et al. 2020), implying that these $D$. pertusum phylotypes may be particularly unusual in their compatibility with rapid shifts in temperature.

The functional diversity revealed from coral-associated Endozoicomonas genomes that have been sequenced underscores the complexity of their codiversification with their hosts (Ding et al. 2016, Neave et al. 2017a, Tandon et al. 2020). This diversity may indicate that different strains of Endozoicomonas can provide unique ecosystem services to their coral host, such as carbohydrate cycling, amino acid synthesis, or production of vitamins and cofactors (Neave et al. 2017a).

\subsection{Conclusions}

Two cold-water scleractinian corals, Desmophyllum dianthus and D. pertusum (Lophelia pertusa) 
that have been combined into a single genus, had significantly different bacterial microbiomes. Benchmark bacterial microbiomes for 2 deep-sea octocorals, Acanthogorgia aspera and A. spissa, were found to be statistically indistinguishable and dominated by Endozoicomonas. This is the first report of coral microbiomes dominated by Endozoicomonas occurring below $1000 \mathrm{~m}$, at temperatures of $3.9-4.5^{\circ} \mathrm{C}$. Distinct and diverse genotypes of Endozoicomonas unexpectedly dominated the microbiome of $D$. pertusum at Richardson Ridge and Cape Fear sites. All prior studies of $D$. pertusum in other regions found this genus to be rare or absent, even when present in neighboring coral Madrepora oculata. The unusual microbiomes at these sites may be linked to the extreme variability experienced by these corals due to interactions with the Gulf Stream. Future research directions could include further characterization of these unusual Endozoicomonas genotypes by cultivation and comparative genomics to understand their tolerance of cold temperatures and potentially unique metabolic capabilities.

Acknowledgements. We thank the captains and crews of the RV 'Atlantis' and NOAA ships 'Ronald H. Brown' and 'Nancy Foster,' and the submersible groups supporting 'Jason II' and 'Alvin' (WHOI), and 'Odysseus' (Pelagic Research Services). We also acknowledge the chief scientists of the various expeditions: Deepwater Canyons, Sandra Brooke (University of Florida) and Steve Ross (University of North Carolina Wilmington); 2017 Southeast Deep Coral Initiative, Peter Etnoyer (NOAA) and Daniel Wagner (NOAA); and DeepSEARCH, Erik Cordes (Temple University) and Amanda Demopoulos (USGS). We thank Michael Gray and D. Katharine Coykendall (formerly USGS) for at-sea collections. Scott France (University of Louisiana at Lafayette), Andrea Quattrini (Smithsonian Institution), and Catherine McFadden (Harvey Mudd College) confirmed octocoral host species identities. We thank Breanna Williams and Betsy Boynton (USGS) for producing the map. This project was sponsored by the National Oceanographic Partnership Program with funding from the Bureau of Ocean Energy Management (contract M17PC00009), the USGS, and the NOAA Office of Ocean Exploration and Research (for ship time). Any use of trade, firm, or product names is for descriptive purposes only and does not imply endorsement by the US Government.

\section{LITERATURE CITED}

Addamo AM, Vertino A, Stolarski J, García-Jiménez R, Taviani M, Machordom A (2016) Merging scleractinian genera: the overwhelming genetic similarity between solitary Desmophyllum and colonial Lophelia. BMC Evol Biol 16:108

Anderson MJ (2001) A new method for non-parametric multivariate analysis of variance. Austral Ecol 26:32-46

Anderson MJ, Walsh DCI (2013) PERMANOVA, ANOSIM, and the Mantel test in the face of heterogeneous disper- sions: What null hypothesis are you testing? Ecol Monogr 83:557-574

Apprill A, Weber LG, Santoro AE (2016) Distinguishing between microbial habitats unravels ecological complexity in coral microbiomes. mSystems 1:e00143-16

Bane JM Jr, Brooks DA (1979) Gulf Stream meanders along the continental margin from the Florida Straits to Cape Hatteras. Geophys Res Lett 6:280-282

Bayer T, Arif C, Ferrier-Pagès C, Zoccola D, Aranda M, Voolstra CR (2013a) Bacteria of the genus Endozoicomonas dominate the microbiome of the Mediterranean gorgonian coral Eunicella cavolini. Mar Ecol Prog Ser 479:75-84

Bayer T, Neave MJ, Alsheikh-Hussain A, Aranda M and others (2013b) The microbiome of the Red Sea coral Stylophora pistillata is dominated by tissue-associated Endozoicomonas bacteria. Appl Environ Microbiol 79: 4759-4762

Bolyen E, Rideout JR, Dillon MR, Bokulich NA and others (2019) Reproducible, interactive, scalable and extensible microbiome data science using QIIME 2. Nat Biotechnol 37:852-857

Bray JR, Curtis JT (1957) An ordination of the upland forest communities of southern Wisconsin. Ecol Monogr 27: 325-349

*Brener-Raffalli K, Clerissi C, Vidal-Dupiol J, Adjeroud M and others (2018) Thermal regime and host clade, rather than geography, drive Symbiodinium and bacterial assemblages in the scleractinian coral Pocillopora damicornis sensu lato. Microbiome 6:39

Brooke S, Järnegren J (2013) Reproductive periodicity of the scleractinian coral Lophelia pertusa from the Trondheim Fjord, Norway. Mar Biol 160:139-153

Brooke SD, Watts MW, Heil AD, Rhode M and others (2017) Distributions and habitat associations of deep-water corals in Norfolk and Baltimore Canyons, Mid-Atlantic Bight, USA. Deep Sea Res II 137:131-147

Buhl-Mortensen L, Mortensen PB (2004) Symbiosis in deepwater corals. Symbiosis 37:33-61

Buhl-Mortensen L, Mortensen PB (2005) Distribution and diversity of species associated with deep-sea gorgonian corals off Atlantic Canada. In: Freiwald A, Roberts JM (eds) Cold-water corals and ecosystems. Springer-Verlag, Berlin, p 849-879

* Callahan BJ, McMurdie PJ, Rosen MJ, Han AW, Johnson AJA, Holmes SP (2016) DADA2: high resolution sample inference from Illumina amplicon data. Nat Methods 13: 581-583

Camp EF, Suggett DJ, Pogoreutz C, Nitschke MR and others (2020) Corals exhibit distinct patterns of microbial reorganisation to thrive in an extreme inshore environment. Coral Reefs 39:701-716

* Caporaso JG, Lauber CL, Walters WA, Berg-Lyons D and others (2011) Global patterns of 16S rRNA diversity at a depth of millions of sequences per sample. Proc Natl Acad Sci USA 108:4516-4522

Chapron L, Lartaud F, Le Bris N, Peru E, Galand PE (2020) Local variability in microbiome composition and growth suggests habitat preferences for two reef-building coldwater coral species. Front Microbiol 11:275

Clarke KR (1993) Non-parametric multivariate analyses of changes in community structure. Aust J Ecol 18:117-143

Cordes EE, McGinley MP, Podowski EL, Becker EL, LessardPilon S, Viada ST, Fisher CR (2008) Coral communities of the deep Gulf of Mexico. Deep Sea Res I 55:777-787 
DeSantis TZ, Hugenholtz P, Larsen N, Rojas M and others (2006) Greengenes, a chimera-checked 16S rRNA gene database and workbench compatible with ARB. Appl Environ Microbiol 72:5069-5072

*Ding JY, Shiu JH, Chen WM, Chiang YR, Tang SL (2016) Genomic insight into the host-endosymbiont relationship of Endozoicomonas montiporae CL- $33^{\mathrm{T}}$ with its coral host. Front Microbiol 7:251

Faith DP (1992) Conservation evaluation and phylogenetic diversity. Biol Conserv 61:1-10

Galand PE, Chapron L, Meistertzheim AL, Peru E, Lartaud F (2018) The effect of captivity on the dynamics of active bacterial communities differs between two deep-sea coral species. Front Microbiol 9:2565

* Galand PE, Remize M, Meistertzheim AL, Pruski AM and others (2020) Diet shapes cold-water corals bacterial communities. Environ Microbiol 22:354-368

Galkiewicz JP, Pratte ZA, Gray MA, Kellogg CA (2011) Characterization of culturable bacteria isolated from the cold-water coral Lophelia pertusa. FEMS Microbiol Ecol 77:333-346

*Galkiewicz JP, Stellick SH, Gray MA, Kellogg CA (2012) Cultured fungal associates from the deep-sea coral Lophelia pertusa. Deep Sea Res I 67:12-20

Gignoux-Wolfsohn SA, Aronson FM, Vollmer SV (2017) Complex interactions between potentially pathogenic, opportunistic, and resident bacteria emerge during infection on a reef-building coral. FEMS Microbiol Ecol 93:fix080

Goldsmith DB, Kellogg CA, Morrison CL, Gray MA and others (2018) Comparison of microbiomes of cold-water corals Primnoa pacifica and Primnoa resedaeformis, with possible link between microbiome composition and host genotype. Sci Rep 8:12383

Gray MA, Stone RP, McLaughlin MR, Kellogg CA (2011) Microbial consortia of gorgonian corals from the Aleutian Islands. FEMS Microbiol Ecol 76:109-120

Guppy R, Bythell JC (2006) Environmental effects on bacterial diversity in the surface mucus layer of the reef coral Montastraea faveolata. Mar Ecol Prog Ser 328:133-142

*Hansson L, Agis M, Maier C, Weinbauer MG (2009) Community composition of bacteria associated with coldwater coral Madrepora oculata: within and between colony variability. Mar Ecol Prog Ser 397:89-102

*Herlemann DPR, Labrenz $M$, Jürgens $K$, Bertilsson S, Waniek JJ, Andersson AF (2011) Transitions in bacterial communities along the $2000 \mathrm{~km}$ salinity gradient of the Baltic Sea. ISME J 5:1571-1579

Hernandez-Agreda A, Leggat W, Bongaerts P, Ainsworth TD (2016) The microbial signature provides insight into the mechanistic basis of coral success across reef habitats. mBio 7:e00560-16

Jaccard P (1908) Nouvelles recherches sur la distribution florale. Bull Soc Vaud Sci Nat 44:223-270

Kellogg CA (2019) Microbiomes of stony and soft deep-sea corals share rare core bacteria. Microbiome 7:90

Kellogg CA, Lisle JT, Galkiewicz JP (2009) Culture-independent characterization of bacterial communities associated with the cold-water coral Lophelia pertusa in the northeastern Gulf of Mexico. Appl Environ Microbiol 75: 2294-2303

Kellogg CA, Ross SW, Brooke SD (2016) Bacterial community diversity of the deep-sea octocoral Paramuricea placomus. PeerJ 4:e2529

Kellogg CA, Goldsmith DB, Gray MA (2017) Biogeographic comparison of Lophelia-associated bacterial communities in the western Atlantic reveals conserved core microbiome. Front Microbiol 8:796

* Kruskal WH, Wallis WA (1952) Use of ranks in one-criterion variance analysis. J Am Stat Assoc 47:583-621

Kumar S, Stecher G, Li M, Knyaz C, Tamura K (2018) MEGA $\mathrm{X}$ : Molecular evolutionary genetics analysis across computing platforms. Mol Biol Evol 35:1547-1549

La Rivière M, Garrabou J, Bally M (2015) Evidence for host specificity among dominant bacterial symbionts in temperate gorgonian corals. Coral Reefs 34:1087-1098

K Lawler SN, Kellogg CA, France SC, Clostio RW, Brooke SD, Ross SW (2016) Coral-associated bacterial diversity is conserved across two deep-sea Anthothela species. Front Microbiol 7:458

* Lee OO, Yang J, Bougouffa S, Wang Y and others (2012) Spatial and species variations in bacterial communities associated with corals from the Red Sea as revealed by pyrosequencing. Appl Environ Microbiol 78:7173-7184

* Lee STM, Davy SK, Tang SL, Kench PS (2017) Water flow buffers shifts in bacterial community structure in heatstressed Acropora muricata. Sci Rep 7:43600

Legeckis RV (1979) Satellite observations of the influence of bottom topography on the seaward deflection of the Gulf Stream off Charleston, South Carolina. J Phys Oceanogr 9:483-497

* Littman RA, Willis BL, Pfeffer C, Bourne DG (2009) Diversities of coral-associated bacteria differ with location, but not species, for three acroporid corals on the Great Barrier Reef. FEMS Microbiol Ecol 68:152-163

* Lozupone C, Knight R (2005) UniFrac: a new phylogenetic method for comparing microbial communities. Appl Environ Microbiol 71:8228-8235

* Lozupone CA, Hamady M, Kelley ST, Knight R (2007) Quantitative and qualitative (beta) diversity measures lead to different insights into factors that structure microbial communities. Appl Environ Microbiol 73:1576-1585

* Maher RL, Rice MM, McMinds R, Burkepile DE, Vega Thurber R (2019) Multiple stressors interact primarily through antagonism to drive changes in the coral microbiome. Sci Rep 9:6834

McCauley M, Jackson CR, Goulet TL (2020) Microbiomes of Caribbean octocorals vary over time but are resistant to environmental change. Front Microbiol 11:1272

* Meistertzheim AL, Lartaud F, Arnaud-Haond S, Kalenitchenko D, Bessalam M, Le Bris N, Galand PE (2016) Patterns of bacteria-host associations suggest different ecological strategies between two reef building coldwater coral species. Deep Sea Res I 114:12-22

*Mienis F, Duineveld GCA, Davies AJ, Lavaleye MSS and others (2014) Cold-water coral growth under extreme environmental conditions, the Cape Lookout area, NW Atlantic. Biogeosciences 11:2543-2560

Morrow KM, Moss AG, Chadwick NE, Liles MR (2012) Bacterial associates of two Caribbean coral species reveal species-specific distribution and geographic variability. Appl Environ Microbiol 78:6438-6449

* Morrow KM, Bourne DG, Humphrey C, Botté ES and others (2015) Natural volcanic $\mathrm{CO}_{2}$ seeps reveal future trajectories for host-microbial associations in corals and sponges. ISME J 9:894-908

Neave MJ, Apprill A, Ferrier-Pagès C, Voolstra CR (2016) Diversity and function of prevalent symbiotic marine bacteria in the genus Endozoicomonas. Appl Microbiol Biotechnol 100:8315-8324 
Neave MJ, Michell CT, Apprill A, Voolstra CR (2017a) Endozoicomonas genomes reveal functional adaptation and plasticity in bacterial strains symbiotically associated with diverse marine hosts. Sci Rep 7:40579

Neave MJ, Rachmawati R, Xun L, Michell CT, Bourne DG, Apprill A, Voolstra CR (2017b) Differential specificity between closely related corals and abundant Endozoicomonas endosymbionts across global scales. ISME J 11:186-200

Neulinger SC, Järnegren J, Ludvigsen M, Lochte K, Dullo WC (2008) Phenotype-specific bacterial communities in the cold-water coral Lophelia pertusa (Scleractinia) and their implications for the coral's nutrition, health, and distribution. Appl Environ Microbiol 74:7272-7285

* Neulinger SC, Gärtner A, Järnegren J, Ludvigsen M, Lochte K, Dullo WC (2009) Tissue-associated 'Candidatus Mycoplasma corallicola' and filamentous bacteria on the coldwater coral Lophelia pertusa (Scleractinia). Appl Environ Microbiol 75:1437-1444

*Pantos O, Bongaerts P, Dennis PG, Tyson GW, Hoegh-Guldberg $O$ (2015) Habitat-specific environmental conditions primarily control the microbiomes of the coral Seriatopora hystrix. ISME J 9:1916-1927

Pielou EC (1966) The measurement of diversity in different types of biological collections. J Theor Biol 13:131-144

* Pogoreutz C, Rädecker N, Cárdenas A, Gärdes A, Wild C, Voolstra CR (2018) Dominance of Endozoicomonas bacteria throughout coral bleaching and mortality suggests structural inflexibility of the Pocillopora verrucosa microbiome. Ecol Evol 8:2240-2252

Pollock FJ, McMinds R, Smith S, Bourne DG and others (2018) Coral-associated bacteria demonstrate phylosymbiosis and cophylogeny. Nat Commun 9:4921

Popenoe P (1994) Bottom character map of the northern Blake Plateau. US Geological Survey Open-File Report 93-724. https://doi.org/10.3133/ofr93724

* Quast C, Pruesse E, Yilmaz P, Gerken J and others (2013) The SILVA ribosomal RNA gene database project: improved data processing and web-based tools. Nucleic Acids Res 41:D590-D596

Reigel AM, Owens SM, Hellberg ME (2020) Reducing host DNA contamination in 16S rRNA gene surveys of anthozoan microbiomes using PNA clamps. Coral Reefs 39: 1817-1827

Reshef L, Koren O, Loya Y, Zilber-Rosenberg I, Rosenberg E (2006) The coral probiotic hypothesis. Environ Microbiol 8:2068-2073

Roberts S, Hirshfield M (2004) Deep-sea corals: out of sight, but no longer out of mind. Front Ecol Environ 2:123-130

* Roberts JM, Wheeler AJ, Freiwald A (2006) Reefs of the deep: the biology and geology of cold-water coral ecosystems. Science 312:543-547

Roberts JM, Wheeler A, Freiwald A, Cairns S (2009) Coldwater corals: the biology and geology of deep-sea coral habitats. Cambridge University Press, Cambridge

* Roder C, Bayer T, Aranda M, Kruse M, Voolstra CR (2015) Microbiome structure of the fungid coral Ctenactis echinata aligns with environmental differences. Mol Ecol 24: 3501-3511

Ross SW, Rhode M, Brooke S (2017) Deep-sea coral and hardbottom habitats on the West Florida Slope, eastern Gulf of Mexico. Deep Sea Res I 127:114-128

Röthig T, Roik A, Yum LK, Voolstra CR (2017a) Distinct bacterial microbiomes associate with the deep-sea coral Eguchipsammia fistula from the Red Sea and from aquaria settings. Front Mar Sci 4:259

Röthig T, Yum LK, Kremb SG, Roik A, Voolstra CR (2017b) Microbial community composition of deep-sea corals from the Red Sea provides insight into functional adaptation to a unique environment. Sci Rep 7:44714

Schöttner S, Hoffmann F, Wild C, Rapp HT, Boetius A, Ramette A (2009) Inter- and intra-habitat bacterial diversity associated with cold-water corals. ISME J 3:756-759

* Shannon CE (1948) The mathematical theory of communication. Bell Syst Tech J 27:379-423

* Shiu JH, Yu SP, Fong CL, Ding JY and others (2020) Shifting in the dominant bacterial group Endozoicomonas is independent of the dissociation with coral symbiont algae. Front Microbiol 11:1791

* Speck MD, Donachie SP (2012) Widespread Oceanospirillaceae bacteria in Porites spp. J Mar Biol 2012:746720

Stanley GD Jr, Cairns SD (1988) Constructional azooxanthellate coral communities: an overview with implications for the fossil record. Palaios 3:233-242

* Stecher G, Tamura K, Kumar S (2020) Molecular evolutionary genetics analysis (MEGA) for macOS. Mol Biol Evol $37: 1237-1239$

Stetson TR, Squires DF, Pratt RM (1962) Coral banks occurring in deep water on the Blake Plateau. Am Mus Novit 2114:1-39

* Stone RP (2006) Coral habitat in the Aleutian Islands of Alaska: depth distribution, fine-scale species associations, and fisheries interactions. Coral Reefs 25: $229-238$

Sunagawa S, Woodley CM, Medina M (2010) Threatened corals provide underexplored microbial habitats. PLOS ONE 5:e9554

Tamura K, Nei M (1993) Estimation of the number of nucleotide substitutions in the control region of mitochondrial DNA in humans and chimpanzees. Mol Biol Evol 10: $512-526$

Tandon K, Lu CY, Chiang PW, Wada N and others (2020) Comparative genomics: dominant coral-bacterium Endozoicomonas acroporae metabolizes dimethylsulfoniopropionate (DMSP). ISME J 14:1290-1303

*Thompson JD, Higgins DG, Gibson TJ (1994) CLUSTAL W: improving the sensitivity of progressive multiple sequence alignment through sequence weighting, positions-specific gap penalties and weight matrix choice. Nucleic Acids Res 22:4673-4680

*T Tsounis G, Orejas C, Reynaud S, Gili JM, Allemand D, Ferrier-Pagès C (2010) Prey-capture rates in four Mediterranean cold water corals. Mar Ecol Prog Ser 398:149-155

*van Bleijswijk JDL, Whalen C, Duineveld GCA, Lavaleye MSS, Witte HJ, Mienis F (2015) Microbial assemblages on a cold-water coral mound at the SE Rockall Bank (NE Atlantic): interactions with hydrography and topography. Biogeosciences 12:4483-4496

*van de Water JAJM, Melkonian R, Voolstra CR, Junca $H$, Beraud E, Allemand D, Ferrier-Pagès C (2017) Comparative assessment of Mediterranean gorgonian-associated microbial communities reveals conserved core and locally variant bacteria. Microb Ecol 73:466-478

*Vega Thurber R, Willner-Hall D, Rodriguez-Mueller B, Desnues C and others (2009) Metagenomic analysis of stressed coral holobionts. Environ Microbiol 11: 2148-2163

* Vezzulli L, Pezzati E, Huete-Stauffer C, Pruzzo C, Cerrano C (2013) 16SrDNA pyrosequencing of the Mediterranean gorgonian Paramuricea clavata reveals a link among 
alterations in bacterial holobiont members, anthropogenic influence and disease outbreaks. PLOS ONE 8: e67745

Voolstra CR, Ziegler M (2020) Adapting with microbial help: Microbiome flexibility facilitates rapid responses to environmental change. BioEssays 42:2000004

Weiler BA, Verhoeven JTP, Dufour SC (2018) Bacterial communities in tissues and surficial mucus of the cold-water coral Paragorgia arborea. Front Mar Sci 5:378

Weinbauer MG, Ogier J, Maier C (2012) Microbial abundance in the coelenteron and mucus of the cold-water coral Lophelia pertusa and in bottom water of the reef environment. Aquat Biol 16:209-216

Editorial responsibility: Jeroen Ingels,

St. Teresa, Florida, USA

Reviewed by: S. Dufour, C. Voolstra
Yakimov MM, Cappello S, Crisafi E, Tursi A and others (2006) Phylogenetic survey of metabolically active microbial communities associated with the deep-sea coral Lophelia pertusa from the Apulian plateau, Central Mediterranean Sea. Deep Sea Res I 53:62-75

Zaneveld JR, Burkepile DE, Shantz AA, Pritchard C and others (2016) Overfishing and nutrient pollution interact with temperature to disrupt coral reefs down to microbial scales. Nat Commun 7:11833

Ziegler M, Grupstra CGB, Barreto MM, Eaton M and others (2019) Coral bacterial community structure responds to environmental change in a host-specific manner. Nat Commun 10:3092

Submitted: March 5, 2021

Accepted: July 26, 2021

Proofs received from author(s): August 26, 2021 